\title{
PELAKSANAAN HAK KEKAYAAN INTELEKTUAL SEBAGAI OBJEK WAKAF
}

\author{
Puji Sulistyaningsih, Heniyatun, Chrisna Bagus Edhita Praja, Dasep Nurjaman \\ Universitas Muhammadiyah Magelang
}

Contact: pujisulistyaningsih@gmail.com; heniyatun@gmail.com;

chrisnabagus@ummgl.ac.id; dasepnurjaman447190011@gmail.com

Diterima: 28 Juni 2019

Direvisi: 29 Juni 2019

Disetujui: 5 Agustus 2019

Hak Cipta: (C) 2018

Halaman: 14-22

\begin{abstract}
This study aims to determine the Islamic view of IPR as a waqf object, and procedures for implementing waqf with IPR objects. This study uses a normative juridical method with an approach to the Law and conceptual approach. The results showed that IPR was seen as one of the wealth rights (Huquq Maliyyah) in the view of Islam that received legal protection as other assets, so that IPR could be used as an object of waqf (al-mauqud 'alaih) both exchange contracts, commercial (Mu'awadhah ) and non-commercial contracts (tabarru'at). IPR as a waqf object is permitted by Islamic law as long as it fulfills the requirements as an object of waqf, as well as positive Indonesian law, this is reinforced by Law No. 41 of 2004 concerning Endowments; Government Regulation No. 42 of 2006; The decision of the Indonesian Ulema Council (MUI) No. 1 MUNAS / VII / $5 / 2005$, allows IPR as an object of waqf. The HKI waqf procedure, in general, is not much different from the waqf procedure with objects of immovable objects such as land or other immovable objects but the difference is that there must be authentic evidence from the Directorate General of Islamic Education and the establishment of court states that the waqf object is not in dispute. Before the waqf pledge was made the Acting Actor of the Pledge of Endowments (PPAIW) consulted the Ministry of Religion in advance to get recommendations.
\end{abstract}




\section{PENDAHULUAN}

Wakaf di Indonesia dalam perkembanganya telah mengalami perubahan yaitu sejak adanya UndangUndang Nomor 41 Tahun 2004 Tentang Wakaf. Berdasarkan ketentuan Pasal 16 ayat (1) Undang-undang Wakaf disebutkan harta benda wakaf terdiri dari benda yang bergerak dan benda yang tidak bergerak, selanjutnya dalam ayat (2) dijelaskan benda tidak bergerak adalah hak atas tanah sesuai dengan ketentuan peraturan perundang-undangan yang berlaku baik yang sudah maupun yang belum terdaftar, bangunan atau bagian bangunan yang berdiri di atas tanah, tanaman dan benda lain yang berkaitan dengan ketentuan peraturan perundang-undangan yang berlaku, benda tidak bergerak lain sesuai dengan ketentuan syariah dan peraturan perundang-undangan yang berlaku. Pasal 16 ayat (3) menjelaskan tentang benda bergerak yaitu harta yang tidak habis gerak saja, padahal wakaf juga bisa berupa benda bergerak antara lain uang, surat berharga, kendaraan, hak kekayaan intelektual (HKI), dan hak sewa (Susanto, 2016).

Islam memberikan kebebasan kepada pemeluknya untuk mengumpulkan harta kekayaan di atas prinsip bahwa sebagian dari harta itu adalah milik orang lain. Bagaimanapun manusia harus mematuhi kehendak pemilik mutlak. Di dalam Islam tidak di kenal dengan adanya kepemilikan yang mutlak (absolute), tetapi kepemilikan majazi (relative). Pemilik mutlak hanya milik Allah SWT, sedangkan manusia hanyalah sekedar pemilik sementara. Selaku pemegang amanah, yang maksudnya harta itu sebagian disalurkan kepada pihak-pihak yang berhak. Penyaluran harta tersebut bisa melalui berbagai pintu diantaranya adalah waqf ( Cahyo, 2012). dikonsumsi yaitu meliputi uang, logam mulia, surat berharga, kendaraan, hak atas kekayaan intelektual, hak sewa dan benda bergerak lain sesuai dengan ketentuan syariah dan peraturan perundangundangan yang berlaku. Adapun berdasarkan ketentuan Peraturan Pemerintah Pasal 1 ayat (1) bahwa "Wakaf adalah hukum wakif untuk memisahkan dan/atau menyerahkan sebagian harta benda miliknya untuk dimanfaatkan selamanya atau untuk jangka waktu tertentu sesuai dengan kepentinganya guna keperluan ibadah dan atau kesejahteraan umum menurut syariah.

Pemahaman masyarakat tentang hukum wakaf, pada umumnya masih banyak yang beranggapan bahwa wakaf hanya boleh digunakan untuk tujuan ibadah khusus saja, seperti untuk masjid, pemakaman, panti asuhan, dan lain-lain. Selain itu pemahaman masyarakat tentang objek wakaf hanya sebatas pada benda tidak ber

Namun dalam perkembangannya berdasarkan Undang-Undang Wakaf, maka Hak Kekayaan Intelektual (HKI) dapat di jadikan sebagai objek wakaf. Akan tetapi perlu dipahami bahwa Hak Kekayaan Intelektual (HKI) kepemilikan haknya dibatasi oleh waktu, sementara dalam Undang-Undang Wakaf maupun Peraturan Pemerintah No 42 Tahun 2006 tidak menentukan jangka waktu untuk pelaksanaan wakaf, terutama terhadap benda tidak bergerak, seperti tanah dan/atau bangunan. Pada dasarnya pelaksanaan wakaf adalah untuk jangka waktu yang tidak ditentukan (abadi) dan untuk kesejahteraan umum bagi masyarakat. Ketentuan Pasal 27 Peraturan Pemerintah No 42 Tahun 2006 mengatur khusus norma ketentuan bagi wakif yang menghendaki adanya jangka waktu tertentu dalam hal wakaf yang diberikan berupa benda bergerak dalam bentuk uang. 
Pemberian wakaf yang berupa uang biasanya diberikan tanpa ditentukan jangka waktu. Hal ini dikarenakan perspektif masyarakat secara umum yang menganggap bahwa wakaf disamakan dengan pemberian untuk ibadah, sehingga memberi dimaksudkan untuk tidak mengaharapkan di kembalikan. Yang membedakan wakaf dengan pemberian biasa adalah peruntukan pemanfaatan atas objek wakaf telah ditentukan sebelumnya. (Gozali, 2016).

Adanya perluasan objek wakaf benda bergerak tidak berwujud dalam bentuk Hak Kekayaan Intelektual (HKI) menyebabkan wakaf atas Hak Kekayaan IntelektuaI (HKI) tersebut dapat digolongkan ke dalam ketentuan wakaf dengan jangka waktu tertentu, hal ini karena perlindungan Hak Kekayaan Intelektual (HKI) memiliki batas waktu sesuai dengan Undang-Undang yang menyatakan jenis-jenis Hak Kekayaan Intelektual (HKI) misalnya Hak Cipta, Paten, Merek, Perlindungan Varietas Tanaman, Desain Industri, Desain Tata Letak Sirkuit Terpadu, Rahasia Dagang. Berdasarkan hal tersebut maka yang menjadi persoalan adalah batasan waktu perlindungan hukum dalam Hak Kekayaan Intelektual (HKI) sebagai objek wakaf, bagaimana pelaksanaanya wakaf tersebut jika hanya untuk sementara waktu.

Berdasarkan hal tersebut maka penulis tertarik untuk melakukan penelitian tentang sejauh mana tingkat akurasi kebenaran dan relevansi antara Hukum Islam dan Undang-Undang wakaf di Indonesia, karena masyarakat Islam secara normatif mempunyai hubungan yang relasional dengan Fiqh serta UndangUndang Wakaf.

\section{METODOLOGI PENELITIAN}

Metode pendekatan yang penulis gunakan dalam penelitian ini yuridis normatif yaitu dengan cara pendekatan ilmiah untuk menemukan suatu kebenaran berdasarkan keilmuan hukum, dan bahan pustaka yang merupakan data sekunder dan disebut penelitian kepustakaan atau penelitian hukum doktriner (Suratman \& Dillah, 2014), dan juga dengan pendekatan konseptual (conceptual approach) (Marzuki, 2015) yaitu dengan mempelajari doktrin-doktrin di dalam hukum Islam dan ilmu hukum, sehingga penulis dapat membangun argumentasi serta konsep hukum dalam memecahkan permasalahan hukum yang sedang dihadapi. Selain itu juga menggunakan pendekatan perundangundangan (statue approach) (Marzuki, 2015), yaitu dengan menelaah Kompilasi Hukum Islam, dan Undang-Undang No 41 Tahun 2004 Tentang Wakaf dan Peraturan Pemerintah No 42 Tahun 2006 Tentang Pelaksanaan Undang-Undang No 41 Tahun 2004 Tentang Wakaf. Penelitian ini memfokuskan pada Wakaf Hak Kekayaan Intelektual Sebagai Objek Wakaf.

Bahan penelitian meliputi data primer dan data sekunder. Data primer penulis memperolehnya dari lapangan yaitu dilakukan dengan wawancara dengan responden, sedangkan untuk mendapatkan data sekunder peneliti memperolehnya melalui studi pustaka yang meliputi bahan hukum primer dan bahan hukum sekunder.

Penentuan responden didasarkan pada metode Non random sampling/purposive sampling yang artinya penetapan sampel berdasarkan ciri-ciri khusus yang mempunyai hubungan dengan permasalahan yang diteliti (Soekanto, 2015). Sampel yang diambil adalah di 
wilayah Kabupaten Magelang dan Kota Magelang.

Alat penelitian yang peneliti pergunakan adalah studi kepustakaan, peneliti menelaah bahan-bahan hukum berupa perundang-undangan, literatur yang berkaitan dengan permasalahan yang diteliti untuk mendapatkan teori yang benar, serta wawancara langsung kepada responden dengan bertanya langsung guna mendapatkan informasi.

Metode analisa data yang digunakan adalah metode induktif, yaitu menarik dari hal yang sifatnya khusus untuk ditarik dan dicari generalisasinya yang bersifat umum untuk megetahui keabsahan Hak Kekayaan Intelektual (HKI) Sebagai Objek Wakaf menurut pandangan hukum Islam.

\section{HASIL DAN PEMBAHASAN}

\section{Pandangan Islam Terhadap Hak Kekayaan Intelektual (HKI) Sebagai Objek Wakaf.}

Menurut Jumhur Ulama harta tidak hanya bersifat materi saja tetapi termasuk dari pemanfaatan dari benda tersebut. Hal tersebut jauh berbeda dengan pendapat Hanafi bahwa harta itulah yang bersifat materi dan manfaatnya termasuk dalam kepemilikan. Sedangkan Syafi'iyah dan Hambaliyah berpendapat sebaliknya. Pandangan pendapatnya bahwa manfaatnya itulah adalah amwal mutaquwwamah, manfaatnyalah yang sebenarnya dimaksud benda tersebut. (Choirulliza, 2009).

Mazhab Maliki berpendapat dari Syaikh AlAllamah Muhammad (Khairuddin, 2014) bahwa sesuatu yang diwakafkan itu bisa untuk selamanya atau boleh dalam waktu tertentu, artinya boleh tidak melepaskan kepemilikan wakif namun wakaf tersebut mencegah wakif melakukan tindakan yang dapat melepaskan kepemilikannya atas harta tersebut kepada yang lain dan wakif berkewajiban menyedekahkan manfaatnya serta tidak boleh menarik kembali wakafnya. Perbuatan menjadikan manfaat hartanya untuk digunakan oleh mauquf bih (penerima wakaf), walaupun yang demikian itu berbentuk upah, atau menjadikan hasilnya untuk dapat digunakan seperti mewakafkan uang. Adapun Mazhab Syafii dan Hambali wakaf adalah tidak melakukan suatu tindakan atas suatu benda yang berstatus sebagai milik Allah SWT dengan menyedekahkan manfaatnya kepada kebajikan (sosial) (Heniyatun, 2017).

Menurut pendapat Ibn"Arafah bahwa harta mencakup benda (ain) yang bisa di indra benda (ard) yang tidak bisa di indranya yaitu manfaatnya. Ibn Arafah mendefinisikan al-raad sebagai manfaat yang secara akal tidak mungkin menunjuk kepadanya. Manfaatnya dikategorikan sebagai harta sebagaimana berlakunya sifat kehartaan kepada benda, maka terhadap manfaat juga berlaku hak milik sebagaimana benda, selama pemanfaatanya tersebut dibolehkan menurut syara (Choirulliza, 2009).

Berdasarkan Ketentuan Undang-Undang Hak Kekayaan Intelektual (HKI) mengenai ketujuh rezim Hak Kekayaan Intelektual (HKI) tidak secara tegas dinyatakan dalam setiap Undang-Undang Hak Kekayaan Intelektual (HKI) peralihanya bisa dijadikan sebagai objek wakaf diantarannya yang bisa dijadikan objek wakaf adalah Hak Cipta dapat beralih atau dialihkan baik seluruh maupun sebagian karena wakaf, ketentuan tersebut telah diatur dalam Pasal 16 Ayat (2) huruf c Undang-Undang Hak Cipta No 28 Tahun 2014; Hak atas Merek terdaftar dapat beralih atau dialihkan karena wakaf telah diatur dalam Pasal 41 ayat (1) huruf c 
Undang-Undang No 20 Tahun 2016 ; Hak Paten dapat beralih atau dialihkan baik seluruhnya maupun sebagian karena wakaf, telah diatur secara jelas peralihanya dalam Pasal 74 ayat (1) huruf d UndangUndang No 13 Tahun 2016 (Praja, Mulyadi, Riswandi, \& Arifah, 2018).

Adapun jenis Hak Kekayaan Intelektual (HKI) yang di dalam Undang-undangnya tidak mengatur secara tegas peralihan dengan wakaf yaitu Hak Rahasia Dagang, Hak Desain Industri, Hak Perlindungan Varietas Tanaman dan Desain Tata Letak Sirkuit Terpadu.

Berdasarkan ketentuan tersebut diatas bahwa sebenarnya semua jenis Hak Kekayaan Intelektual (HKI) dapat beralih dan dialihkan melalui wakaf. Hal ini dapat dilihat dalam Pasal 5 ayat (1) huruf e Undang-Undang Rahasia Dagang No 30 Tahun 2000 ; Pasal 23 ayat (1) huruf e Undang-Undang Desain Tata Letak Sirkuit Terpadu No 32 Tahun 2000 ; Pasal 40 ayat (1) huruf e Undang-Undang Perlindungan Varietas Tanaman No 29 Tahun 2000 ; Pasal 31 ayat (1) huruf e Undang-Undang Desain Industri No 31 Tahun 2000 ; ketentuan tersebut menyebutkan bahwa peralihan Hak Kekayaan Intelektual (HKI) tersebut dapat dialihkan berdasarkan sebab-sebab lain yang diatur dalam peraturan perundang-undangan.

Berdasarkan pandangan termasuk Pejabat pembuat Akta Ikrar Wakaf (PPAIW) secara keseluruhan bahwa Hak Kekayaan Intelektual (HKI) dapat dijadikan sebagai objek wakaf dengan mengikuti aturan yang tertulis yaitu undang-undang wakaf sebagai pedomanya dan mendapatkan rekomendasi dari Kemenag terlebih dahulu atas pelaksanaan Hak Kekayaan Intelektual (HKI) sebagai objek wakaf.

Peneliti menanggapi atas pendapat dari responden secara umum Hak Kekayaan Intelektual (HKI) dapat dijadikan sebagai objek wakaf dan diperbolehkan, Namun ada satu pendapat yang berbeda dari Helza Novalita selaku Perwakilan Badan Wakaf Indonesia (BWI) yang menyatakan secara keseluruhan Hak Kekayaan Intelektual (HKI) dari ketujuh rezim tersebut dapat dijadikan sebagai objek wakaf kecuali Hak Rahasia Dagang tidak dapat dijadikan sebagai objek wakaf perlu adanya kajian khusus tentang Rahasia Dagang sebagai objek wakaf.

Berdasarkan hasil wawancara dengan para responden menunjukan bahwa pandangan terhadap Hak Kekayaan Intelektual (HKI) sebagai objek wakaf diperbolehkan secara hukum Islam maupun hukum positif Indonesia, karena telah diatur dalam Undang-Undang No 41 Tahun 2004 tentang wakaf yang merupakan dasar dalam menentukan Hak Kekayaan Intelektual (HKI) sebagai objek wakaf, secara garis besar responden telah sepakat bahwa Hak Kekayaan Intelektual (HKI) dapat dijadikan sebagai objek wakaf meskipun ada satu pandangan dari Majelis Ulama Indonesia (MUI) Kabupaten Magelang tidak setuju dan tidak diperbolehkan jika wakaf Hak Kekayaan Intelektual (HKI) sebagai objek wakaf yang mempunyai jangka waktu terbatas maka tidak sah jika wakafnya dengan muaqqatan/sementara. Namun beliau setuju Hak Kekayaan Intelektual (HKI) dijadikan sebagai objek wakaf apabila telah adanya Putusan Fatwa MUI tentang wakaf Hak Kekayaan Intelektual (HKI). Secara tersirat sebetulnya beliau menyetujui Hak Kekayaan Intelektual (HKI) sebagai objek wakaf, yaitu dengan pernytaan beliau yang menyatakan bahwa Hak Kekayaan Intelektual (HKI) diwakafkan selamanya sampai tidak ada manfaatnya. Artinya pernyataan tersebut selama waktu perlindungan Hak Kekayaan Intelektual (HKI) sampai habis masa waktu 
disitulah tidak ada manfaatnya lagi.

\section{Prosedur Wakaf Hak Kekayaan Intelektual.}

Berdasarkan hasil wawancara dengan responden khususnya yang terkait langsung menangani wakaf Hak Kekayaan Intelektual (HKI), memberikan gambaran atas prosedur wakaf Hak Kekayaan Intelektual (HKI) secara garis besar hampir sama dengan wakaf benda tidak bergerak, lebih jelasnya prosedur wakaf Hak Kekayaan Intelektual (HKI) yaitu sebagai berikut:

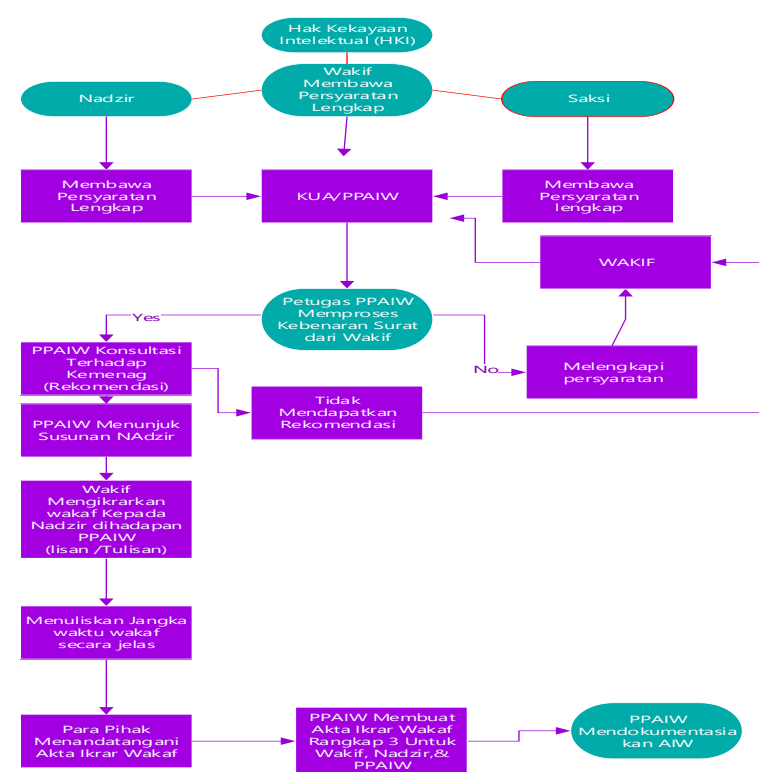

Gambar 1. Prosedur Pelaksanaan Wakaf

Hak Kekayaan Intelelektual

Persyaratan Wakaf Hak Kekayaan Intelektual (HKI) yang harus dipenuhi adalah sebagai berikut :

1. Persyaratan

a. Wakif

1) Syarat wakif adalah yang mempunyai wewenang memberi, merdeka, sempurna akalnya, balig, bijaksana dalam bertindak, bukan orang murtad, pemilik bagi yang diwakafkan serta keinginan sendiri.

2) Persyaratan yang harus dilengkapi wakif :

(1) Foto copy KTP \& Kartu Keluarga 4 lembar

(2) Bukti kepemilikan HKI (sertifikat) dari Ditjen KI

(3) Bukti penetapan atas keterangan kepemilikan HKI dan tidak dalam keadaan sengketa disahkan oleh pengadilan 1 lembar.

(4) Surat pernyataan dari Kades/Lurah setempat disahkan oleh camat

(5) Membawa formulir WK dan WD dari desa (bagi wakif yang telah meninggal dunia)

(6) Membuat surat (blanko yang tersedia di KUA) kuasa kepada PPAIW untuk proses pendaftaran ke badan Wakaf Indonesia (BWI)

(7) Membawa materai 6000

b. Nadzir

1) Syarat Nadzir adalah warga negara Indonesia, beragama Islam, dewasa, amanah, mampu secara jasmani dan rohani, tidak terhalang melakukan perbuatan hukum

2) Persyaratan yang harus dilengkapi Nadzir

a) Photo copy KTP 4 lembar

b) Membawa materai Rp 6000

c. Saksi

1) Syarat Saksi adalah dewasa, beragama Islam, berakal sehat, tidak terhalang melakukan perbuatan hokum

2) Persyaratan yang harus dipenuhi oleh saksi :

a) Foto copy KTP 4 lembar

b) Membawa materai Rp 6000 
2. Prosedur Wakaf Hak Kekayaan Intelektual (HKI)

a. Wakif dan Nadzir serta 2 orang Saksi datang ke Kantor Urusan Agama (KUA) untuk pembuatan Akta Ikrar Wakaf (AIW) di PPAIW dengan masing-masing membawa dokumen persyaratan lengkap

b. Petugas Pejabat Pembuat Akta Ikrar Wakaf (PPAIW) memproses kebenaran surat dari wakif.

c. Petugas Pejabat Pembuat Akta Ikrar Wakaf (PPAIW) jika wakif telah melengkapi persyaratan dan benar maka akan mengkonsultasikan wakaf tersebut kepada Kemenag jika persyaratan wakif tidak lengkap maka akan dikembalikan kepada wakif untuk melengkapi persyaratan wakaf di Kantor Urusan Agama (KUA).

d. Pejabat Pembuat Akta Ikrar Wakaf (PPAIW) akan menunjuk susunan Nadzir

e. Wakif mengikrarkan wakaf kepada Nadzir dihadapan PPAIW secara lisan atau tulisan serta menuliskan jangka waktu wakaf dengan jelas.

f. Para Pihak setelah mengikrarkan wakaf maka menandatangani Akta ikrar wakaf secara lengkap serta Petugas Pejabat Pembuat Akta Ikrar Wakaf (PPAIW) merangkap AIW menjadi 3 rangkap untuk Wakif, Nadzir dan PPAIW, serta mendokumentasikanya.

3. Model Berkas Wakaf (W) di Kantor Urusan Agama (KUA)

a. Bersertifikat Hak Milik

1) Model W1, (ikrar wakaf 1 lembar) PPAIW
2) Model W2, (akta ikrar wakaf 3 lembar) bermaterai 6.000.- untuk PPAIW dan Kementrian Agama serta Ditjen HKI (rancangan juklis para pihak).

3) Model W2.a (Salinan akta ikrar wakaf 4 lembar) lembaran untuk wakif, Nadzir, Keluraha/Desa dan Kemenag.

4) Model W5 (Surat pengesahan Nadzir 8 lembar untuk lembaga/organisasi. 1 lembar arsip KUA, 1 lembar untuk nadzir, 1 lembar untuk kelurahan/desa, 1 lembar untuk lembaga untuk organisasi/yayasan, 1 lembar untuk Ditjen HKI (rancangan juklis para pihak).

5) W7 (surat pengantar permohonan wakaf sesuai dengan objek wakaf dari KUA).

6) Lampiran sertifikat HKI foto copy di sahkan KUA

7) NB : Surat Penetapan dari Pengadilan yang menyatakan bahwa HKI tersebut tidak dalam sengketa.

b. Wakif yang meninggal dunia :

1) Model W1, W3 (akta ikrar wakaf), W5+W7+W3 (salinan akta pengganti AIW).

2) Bersertifikat Hak Milik dan tidak bersertifikat Hak Milik (Model W3.a lembar 1 untuk wakif, lembar 2 nadzir lembar 3 untuk Kelurahan/Desa, lembar 4 Untuk Kemenag.

Berdasarkan hasil wawancara dari para responden maka prosedur wakaf Hak Kekayaan Intelektual (HKI) di atas meskipun di lapangan belum pernah melaksanakan wakaf Hak Kekayaan 
Intelektual (HKI) akan tetapi tidak jauh berbeda dengan wakaf benda tidak bergerak pada umumnya hanya saja tetap ada yang mewakafkan Hak Kekayaan Intelektual (HKI) ke Kantor Urusan Agama (KUA) sesuai dengan persyaratan dan prosedur wakaf seperti wakaf benda tidak bergerak, setelah wakif datang ke Kantor Urusan Agama (KUA) maka petugas dari Pejabat Pembuat Akta Ikrar Wakaf (PPAIW) akan berkonsultasi dengan lembaga di atasnya yaitu (Kemenag) untuk mengkonsultasikan wakaf Hak Kekayaan Intelektual (HKI) tersebut. Karena tujuan untuk mengkonsultasikan terlebih dahulu untuk mengetahui apakah objek wakaf tersebut termasuk melanggar syariah atau tidak. Dengan demikian tetap prosedur pendaftaran masih berpedoman kepada Peraturan Pemerintah No 28 Tahun 1977 dan Undang-Undang No 41 Tahun 2004 serta peraturan pelaksanaanya yaitu Peraturan Pemerintah No 42 Tahun 2006 Tentang Wakaf.

\section{KESIMPULAN}

Pandangan Islam terhadap Hak Kekayaan Intelektual (HKI) sebagai objek wakaf yaitu bahwa Hak Kekayaan Intelektual (HKI) dipandang sebagai salah satu Hak Kekayaan (Huquq Maliyyah) yang mendapatkan perlindungan hukum sebagaimana harta kekayaan dan Hak Kekayaan Intelektual (HKI) dapat dijadikan objek wakaf (al-mauqud 'alaih) baik akad pertukaran, komersial (Mu'awadhah) maupun akad nonkomersial (tabarru'at) dapat diwakafkan. Hak Kekayaan Intelektual (HKI) sebagai objek wakaf diperbolehkan oleh hukum Islam selama terpenuhinya syarat obyek wakaf meskipun wakaf HKI ada pembatasan waktu perlindungan hukumnya/haknya. Namun hal tersebut juga di dukung oleh hukum positif, yaitu oleh Undang-Undang No 41 Tahun 2004 Tentang Wakaf serta
Peraturan Pemerintah No 42 Tahun 2006 serta Keputusan Majelis Ulama Indonesia (MUI) N0 1 MUNAS/VII/5/2005 memperbolehkan Hak Kekayaan Intelektual (HKI) sebagai objek wakaf.

Prosedur wakaf Hak Kekayaan Intelektual (HKI) secara garis besar tidak jauh berbeda dengan prosedur wakaf dengan objek wakaf benda tidak bergerak seperti tanah atau benda tidak bergerak lainya. Namun bedanya untuk prosedur wakaf Hak Kekayaan Intelektual (HKI) wajib menyertakan kepemilikan Hak Kekayaan Intelektual (HKI) dari Ditjen KI dari masing-masing klasifikasi Hak Kekayaan Intelektual (HKI) dan bukti surat pernyataan dari pengadilan yang menyatakan bahwa objek wakaf tersebut tidak dalam keadaan sengketa, serta wajib menuliskan jangka waktu wakaf sesuai keinginan wakif. Namun sebelum dilakukan ikrar wakaf Pejabat Pembuat Akta Ikrar Wakaf (PPAIW) menkonsultasikan terlebih dahulu kepada Kementrian Agama (Kemenag) guna untuk mendapatkan pertimbangan/rekomendasi atas objek wakaf yang di daftarkan. Saat ini prosedur pendaftaran wakaf Hak Kekayaan Intelektual (HKI) masih berpedoman pada Peraturan Pemerintah No 28 Tahun 1977 dan Peraturan Pemerintah No 42 Tahun 2006 atas Pelaksanaan Undang-Undang No 41 Tahun 2004 Tentang Wakaf karena semua peraturan perundang-undangan yang mengatur wakaf masih akan tetap berlaku sepanjang tidak bertentangan dan/atau belum diganti dengan peraturan yang baru.

\section{DAFTAR PUSTAKA}

Choirulliza. (2009). Wakaf Hak Kekayaan Intelektual (HKI) Dalam Hukum Islam. UIN Sunan Kalijaga.

Cahyo, Eko Nur. (2012). No Title. In Ijtihad 
Jurnal Hukum dan Ekonomi Islam (2nd ed., Vol. 7, p. 49). Ponorogo: Fakultas Syariah Darussalam Gontor.

Gozali. (2016). Kajian Kritis Atas Aset Hak Kekayaan Intelektual Sebagai Obyek Wakaf. Yogyakarta: Pustaka Setia.

Heniyatun. (2017). Kajian Yuridis Peralihan Hak Cipta Sebagai Objek. Novelty, 8(1), 94.

Khairuddin. (2014). Pergeseran paradigma pengaturan wakaf dalam perspektif hukum progresif. Al-'Adalah, 12(1), 135-154.

Inpres No. 1 Tahun 1991 Tentang Kompilasi Hukum Islam (KHI).

Keputusan Majelis Ulama Indonesia (MUI) N0 1 MUNAS/VII/5/2005.

Marzuki, Peter Mahmud. (2015). Penelitian Hukum (10th ed.). Jakarta: Prenadamedia Group.

Praja, C. B. E., Mulyadi, Riswandi, B. A., \& Arifah, K. N. (2018). Patent Right Transfer Through Waqf: What are the Requirement? Yustisia, 7(2), 301-313.

Peraturan Pemerintah No 42 Tahun 2006 atas Pelaksanaan Undang-Undang No 41 Tahun 2004 Tentang Wakaf.

Soekanto, Soerjono. (2015). Pengantar Penelitian Hukum (3rd ed.). Jakarta: UIPress.

Suratman \& Dillah, Philips. (2014). Metode Penelitian Hukum (2nd ed.). Bandung: ALFABETA.
Susanto, H. (2016). Eksistensi dan Peran Ekonomis Harta Wakaf. Eksistensi Dan Peran Ekonomis Harta Wakaf, 13(2), 336.

Undang- Undang No 41 Tahun 2004 Tentang Wakaf. 